minimise the risk of personal and family breakdown. New service models will require evaluation.

We thank all families who kindly participated in the study. We are grateful to the Housing Department of the Birmingham City Council, Mrs Daphne Agnew, the staff of the seven hostels, the head teachers of the schools involved in the selection of the comparison sample, and $\mathrm{Mr}$ Saeed Haque for the statistical advice.

Contributors: PV participated in the formulation of the study hypothesis, research design, data analysis and writing of the paper and is the guarantor of the paper. EG completed data collection and participated in data analysis and writing of the paper. SC participated in the formulation of the study hypothesis, research design, data analysis, and writing of the paper.

Funding: Nuffield Foundation.

Conflict of interest: None.

1 Bhugra TS, ed. Homelessness and mental health. Cambridge: Cambridge University Press, 1996.

2 Leff J. All the homeless people-where do they all come from? BMJ 1993;306:669-70.

3 Connelly J, Crown J, eds. Homelessness and ill health:report of a working party of the Royal College of Physicians. London: Royal College of Physicians, 1994

4 Thomas A, Niner P. Living in temporary accommodation: a survey of homeless people. London: HMSO, 1989.

5 Brooks L, Patel M. Homelessness and health: a right to health care, a challenge for the health services. London: Redbridge and Waltham Forest Health Authority, 1995.

6 Conway J, ed. Prescription for poor health: the crisis for homeless families. London: LFC, Maternity Alliance, SHAC, Shelter, 1988.

7 Finkelstein J, Parker R. Homeless children in America: taking the next step. Am J Dis Child 1993;147:520-1.
8 Amery J, Tomkins A, Victor C. The prevalence of behavioural problems amongst homeless primary school children in an outer London borough. Public Health 1995;109:421-4.

9 Vostanis P, Cumella S, Briscoe J, Oyebode F. Psychosocial characteristics of homeless children: a preliminary study. Eur J Psychiatry 1996;10: 108-17.

10 Vostanis P, Cumella S, Grattan E. Psychosocial functioning of homeless children. J Am Acad Child Adol Psychiatry 1997;36:881-9.

11 Victor C, Connelly J, Roderick P, Cohen C. Use of hospital services by homeless families in an inner London health district. BMJ 1989;299: 725-7.

12 Office of Population Censuses and Surveys. Classification of occupations 1980. London: HMSO, 1980.

13 Achenbach T. Manual for the child behaviour checklist/4-18 and 1991 profile. Burlington, VT: University of Vermont, 1991.

14 Achenbach T. Manual for the child behaviour checklist/2-3 and 1992 profile. Burlington, VT: University of Vermont, 1992.

15 Goldberg D. Manual of the general health questionnaire. Windsor: NFER Nelson, 1978.

16 Henderson S, Duncan-Jones P, Byrne D, Scott J. Interview schedule for social interaction. Canberra: Academic Press, 1981.

17 Henderson S, Byrne D, Duncan-Jones P. Neurosis and the social environment. Canberra: Academic Press, 1980.

18 Sparrow S, Bella D, Cicchetti D. Vineland adaptive behaviour scales. Circle Pines, MN: American Guidance Services, 1984.

19 Goldberg D, Huxley P. Common mental disorders: a bio-social model. London: Tavistock, 1992.

20 Heath I. The poor man at his gate: homelessness is an avoidable cause of ill health. BMJ 1995;309:1675-6.

21 Stewart G, Stewart J. Social work with homeless families. Br J Soc Work 1992;22:271-89.

22 Hammond L, Bell J. The setting up of a drop-in service to a homeless families project. Association of Child Psychology and Psychiatry Newsletter $1995 ; 17: 132-8$.

23 Power S, Whitty G, Youdell D. No place to learn: homelessness and education. London: Shelter, 1995.

(Accepted 27 November 1997)

\title{
Rate of recurrent collapse after vaccination with whole cell pertussis vaccine: follow up study
}

\author{
Patricia E Vermeer-de Bondt, Jerry Labadie, Hans C Rümke
}

Editorial by Miller

Laboratory for

Clinical Vaccine

Research, Nationa

Institute of Public

Health and

Environment, PO

Box 1,3720 BA

Bilthoven,

Netherlands

Patricia E

Vermeer-de Bondt,

child health

consultant

Jerry Labadie,

clinical investigator

Hans C Rümke,

paediatrician-

epidemiologist

Correspondence to:

Dr Vermeer-de

Bondt

patricia.vermeer@

rivm.nl

BMJ 1998;316:902-3
Whole cell vaccines against pertussis can induce a hypotonic-hyporesponsive episode or shock-like syndrome (collapse) in children, ${ }^{1}$ but this may also occur with diphtheria and tetanus vaccines, acellular pertussis vaccine, and without vaccination. ${ }^{2}$ Two prospective studies estimated that the rate of collapse after vaccination was considerable (13 out of 35284 and 9 out of 15 752). ${ }^{3}{ }^{4}$ The only follow up study, which assessed a small series, was inconclusive about sequelae. ${ }^{5}$

Comparing the rates of collapse between countries poses problems because of differences in vaccination schedules and vaccines and in the way adverse reactions are monitored and symptoms reported. Moreover, case definitions are inconsistent.

Although the rate of recurrent collapse after whole cell pertussis vaccine has not been studied, for over 30 years repeat doses of vaccine have been contraindicated in children who experience a collapse reaction. Before 1993, in both the Netherlands and the United States children who had had a collapse reaction after vaccination with whole cell pertussis were not given a repeat dose. This contraindication still applies in the Netherlands, although most children are given further doses. We measured the numbers of cases of collapse in children after vaccination with whole cell pertussis vaccine in the Netherlands in 1994 and followed up all cases who were reported after their first dose.

\section{Subjects, methods, and results}

In the Netherlands over $99 \%$ of childhood vaccines are administered routinely by specialised staff within a child health clinic. All vaccinations are registered in provincial databases, so that data are accessible to medical staff if a child changes address. In 1962 an enhanced passive surveillance system for monitoring adverse events following vaccinations, with a 24 hour telephone service, was instigated. Some degree of underreporting is inevitable, but it seems to be limited and not biased against collapse (our laboratory's year report, 1994). Collapse is defined as sudden loss of muscle tone, pallor, and unresponsiveness. Sometimes symptoms are incomplete or atypical. When only one of the symptoms is present, the event is logged as an unspecified minor illness and not collapse.

In 1994, 712 adverse events were reported to the surveillance system, 587 after combined vaccination against diphtheria, tetanus, pertussis, and poliomyelitis (DTP-IPV vaccine) and Haemophilus influenzae type B (Hib-PRP-T vaccine). (The adverse events from $\mathrm{H}$ influenzae type $\mathrm{B}$ vaccine are infrequent and mild and not dealt with here.) After verification of symptoms we diagnosed 134 collapses (table).

In 1996 we followed up the 105 children with collapse reported after their first vaccinations. Detailed 
Numbers of infants in the Netherlands with collapse reactions after vaccination against diphtheria, pertussis, tetanus, and poliomyelitis (DTP-IPV vaccine) with simultaneous Haemophilus influenzae type B vaccination (Hib-PRP-T vaccine) ${ }^{*}$

\begin{tabular}{lrccc} 
& \multicolumn{4}{c}{ Dose } \\
\cline { 2 - 5 } & First & Second & Third & Fourth \\
\hline Scheduled age (months) & 3 & 4 & 5 & 11 \\
\hline No who collapsed & 105 & 19 & 7 & 3 \\
\hline
\end{tabular}

${ }^{*}$ Birth cohort 200000 ; vaccination uptake $97.5 \%$.

information about subsequent vaccinations, health state, and development in 101 of the children was supplied by child health clinics. Four of the children were lost to follow up: two had moved abroad and the names of two were unknown. The parents of one child refused further vaccinations, and 16 children completed their schedule with the combined diphtheria, tetanus, and poliomyelitis vaccine (DT-IPV). The other 84 children received further pertussis vaccine (DTP-IPV), totalling 236 doses; 74 received the full three doses. None of the children had recurrent collapse, and other adverse events were only minor. No systematic precautions were taken, although about half the children were given paracetamol prophylactically for the second vaccination; most of them did not take it for subsequent doses. At the time of follow up the children's health and development showed no particular anomalies. One child who had not received further pertussis vaccinations developed severe pertussis.

\section{Comment}

The risk of recurrent collapse is higher than the background rate, which is low for second and subsequent vaccinations, but our data show that recurrence of collapse is exceptionally low (95\% confidence interval 0\% to $4.3 \%$ ). A scheduled case-control study of all cases reported in 1995 would add to the numbers and contribute towards an understanding of risk factors and the effect of paracetamol used prophylactically.

Our preliminary results suggest that stopping further doses of pertussis vaccine is unneccessary and that vaccinations can still take place in a child healthcare clinic without special precautions. Parents, however, do need guidance and reassurance, and vaccination as an outpatient should be considered in the few cases in which parents' fears are not allayed.

We thank the staff of the child health clinics for providing us with the data.

Contributors: PEV-deB designed the study, assessed the adverse events, designed the follow up study, aquired and analysed the data, and wrote the manuscript; she will act as guarantor of the study. JL designed the study, took part in the surveillance scheme, investigated reports, and helped write the manuscript. HCR designed the study, took part in the surveillance scheme, investigated reports, and helped write the manuscript.

Funding: None.

Conflict of interest: None.

1 Howson CP, Howe CJ, Finberg HV, eds. Adverse effects of pertussis and rubella vaccines: a report of the committee to review the adverse consequences of pertussis and rubella vaccines. Washington, DC: National Academy Press, pertussis

2 Olin P, Gustafsson L, Rasmussen F, Hallander H, Heijbel H, Gottfarb P. Efficacy trial of acellular pertussis vaccines; technical report trial II. Stockholm: Swedish Institute for Infectious Disease Control, 1997.

3 Hannik CA, Cohen H. Pertussis vaccine experience in the Netherlands. In: Manclark CR, Hill JC, eds. Proceedings of the third international symposium on pertussis, Bethesda, 1978. Washington: DHEW Publications, symposium on per $1979 \cdot 279-82$.

4 Cody CL, Baraff LJ, Cherry JD, Marcy SM, Manclark CR. Nature and rates of adverse reactions with DTP and DT immunizations in infants and children. Pediatrics 1981;68:650-60.

5 Baraff LJ, Shields WD, Beckwith L, Strome G, Marcy SM, Cherry JD, et al. Infants and children with convulsions and hypotonic-hyporesponsive episodes following diphtheria-tetanus-pertussis immunization: follow-up evaluation. Pediatrics 1988:81:789-94.

(Accepted 10 October 1997)

\title{
Phantom pain, anxiety, depression, and their relation in consecutive patients with amputated limbs: case reports
}

\author{
K Fisher, R S Hanspal
}

Parkes suggested that emotional factors are influential in patients' experience of prolonged pain in a phantom limb after amputation and concluded that this may be prevented if patients are encouraged to express grief over their loss. ${ }^{1}$ However, Katz and Melzack found no significant difference in standardised tests of psychological dysfunction between patients who experienced phantom pain and those who did not. They concluded that the pain is more likely to vary with the experience of preamputation pain, even retaining many of its characteristics. $^{2}$ A review of the literature on measures used to diagnose psychopathology found that many measures include items that confound emotional distress with the physical disorder and thus overestimate it. ${ }^{3}$ We investigated whether people who had had arms or legs amputated experienced emotional distress, and the relation between the distress and pain, using standardised screening techniques designed for patients with physical illness.

\section{Patients, methods, and results}

Calculations of sample size indicated that 21 patients per group would be needed to show a reliable difference at the $5 \%$ level of significance. The participants were 93 consecutive patients who had been referred to the prosthetic rehabilitation clinic and were aged 34-91 (mean 65) years; 54 were men. Time since amputation was 1-58 (9.7) years. Sixty patients had had a leg amputated for vascular illness, including diabetes, 10 of them losing both legs. Twenty four patients had lost a leg and nine an arm because of trauma. RSH obtained a clinical history including information about previous and concurrent medical and psychiatric problems. Phantom pain was assessed with the short form McGill pain questionnaire, ${ }^{4}$ the patients endorsing all words describing their phantom pain, if present. KF, who was blind to the pain report, then assessed them with the hospital anxiety and depression scale. ${ }^{5}$ 